\title{
EFEKTIVITAS GERAKAN LITERASI 15 MENIT DALAM MENUMBUHKAN MINAT BACA SISWA AUTIS KELAS IV SLB TNCC BANDA ACEH MATA PELAJARAN BAHASA INDONESIA
}

\author{
${ }^{1}$ Mita Helfiana ${ }^{2}$ Nita Sari ${ }^{3}$ Suciani \\ Sekolah Luar Biasa The Nanny Children Centre Banda Aceh, Aceh, Indonesia \\ Koresponden: helfianamita@gmail.com,nitasari928@gmail.com,sucisuci917@gmail.com \\ tncc.indonesia@gmail.com
}

\begin{abstract}
Abstrak
Minat baca merupakan salah satu kunci penting bagi seseorang untuk memperoleh ilmu pengetahuan dan informasi. Jadi dengan membaca, siswa dapat memperoleh pengetahuan yang telah disediakan. Semakin sering seorang siswa membaca, maka pengetahuan dan wawasan yang dimilikinya akan semakin luas. Penelitian ini bertujuan untuk mengetahui keefektivitan Gerakan Literasi 15 Menit dalam Menumbuhkan Minat Baca Pada Siswa Autis Kelas 4 Mata Pelajaran Bahasa Indonesia Pada Materi Teks Cerita Narasi Di SLB TNCC Banda Aceh,Penelitian ini merupakan penelitian kualitatif, dengan Teknik Pengumpulan data meliputi observasi, wawancara dan studi dokumentasi. Adapun subyek dalam penelitian ini adalah Siswa kelas IV Autis SLB TNCC Banda Aceh yang terdiri dari dua orang, dan teknik analisis data dilakukan secara kualitatif dengan tahapan diantaranya ialah: (1) Reduksi data, (2) Penyajian Data. (3) Triangulasi, dan (4) Verifikation/Penarikan Kesimpulan. Berdasarkan hasil penelitian diketahui bahwa Gerakan Literasi 15 menit sebelum Proses Belajar Mengajar (PBM) sangat efektif dilakukan untuk menumbuhkan minat baca siswa pada autis kelas 4. Hal ini dilihat dari hasil ketuntasan indikator keefektifan minat baca, dengan kegiatan Literasi 15 menit siswa autis terdapat perubahan signifikan dalam mengenal huruf dan minat membaca siswa meningkat.
\end{abstract}

Kata Kunci: Gerakan Literasi, Minat Baca, dan Autis

\section{Abstract}

Reading interest is one of the important keys for someone to gain knowledge and information. So by reading, students can get the knowledge that has been provided. The more often a student reads, the broader his knowledge and insight will be. This study aims to determine the effectiveness of the 15 Minute Literacy Movement in Fostering Reading Interest in Class 4 Autistic Students in Indonesian Language Subjects in Narrative Story Text Material at TNCC Banda Aceh Special School. This research is a qualitative research, with data collection techniques including observation, interviews and studies. documentation. The subjects in this study were students of class IV Autism at SLB TNCC Banda Aceh, which consisted of two people, and the data analysis technique was carried out qualitatively with stages including: (1) data reduction, (2) data presentation. (3) Triangulation, and (4) Verification / Conclusion Withdrawal. Based on the results of the study, it is known that the Literacy Movement 15 minutes before the Teaching and Learning Process (PBM) is very effective in cultivating students' reading interest in autism in class 4 . This can be seen from the results of completeness of the indicators of the effectiveness of reading interest, with 15 minutes of Literacy activities for autistic students there are significant changes. in recognizing letters and students' reading interest increases. 
Keywords: Literacy Movement, Reading Interest, and Autism

\section{PENDAHULUAN}

Menurut Umar Tirtarahardja dalam buku pengantar pendidikan, pendidikan adalah suatu proses dalam usaha pencerahan kehidupan manusia. Pendidikan memberikan kemampuan pengembangan pikiran, penataan perilaku dan pengaturan emosi. Melalui pendidikan manusia dapat memecahkan permasalahan antar manusia maupun dengan alam dan sekaligus dapat memanfaatkan alam untuk peningkatan kehidupan. Dengan pendidikan seluruh potensi manusia akan teroptimalkan yakni potensi otak, tubuh dan spiritual. Pendidikan yang mampu mendukung pembangunan dimasa mendatang adalah pendidikan yang mampu mengembangkan potensi peserta didik sehingga yang bersangkutan mampu menghadapi dan memecahkan masalah kehidupan yang dihadapinya. Untuk mencapai itu semua, bisa didapat melalui jalur pendidikan sekolah melalui kegiatan belajar mengajar secara berjenjangan dan berkesinambungan. Sifatnya formal, diatur berdasarkan ketentuan-ketentuan pemerintah dan mempunyai keseragaman pola yang bersifat nasional. ${ }^{1}$ Salah satunya adalah SLB.

Sekolah Luar Biasa (SLB) adalah sebuah lembaga pendidikan formal yang melayani pendidikanbagianak-anakberkebutuhankhusus. Sebagai lembaga pendidikan SLB dibentuk oleh banyak unsur yang diarahkan untuk mencapai tujuan pendidikan, yang proses intinya adalah pembelajaran bagi peserta didik. Jadi SLB

1 Mita Helfiana, "Penguasaan Konsep pada Materi Tata Nama Senyawa Melalui Pembelajaran Berbasis Inkuiri Siswa Kelas X SMAN 1 Labuhanhaji”. E-Skripsi. (Banda Aceh: UIN Ar-Raniry, 2016), h.5. merupakan lembaga pendidikan khusus yang menyelenggarakan program pendidikan bagi anak berkebutuhan khusus. Dalam ketentuan umum Undang-Undang Sisdiknas tahun 2003 Pasal 1 Ayat 1 pembelajaran agar peserta didik secara aktif mengembangkan potensi dirinya, kecerdasan, akhlak mulia, serta keterampilan, yang diperlukan dirinya, masyarakat, dan bangsa. $^{2}$

Bertitik tolak dari tujuan itulah setiap lembaga pendidikan termasuk di dalamnya Sekolah Luar Biasa hendaknya bergerak dari awal hingga akhir sampai titik tujuan suatu proses pendidikan, yang pada akhirnya dapat sebagai suatu proses aktualisasi potensi peserta didik menjadi kompetensi yang dapat dimanfaatkan atau digunakan dalam kehidupan. ${ }^{3}$ SLB dibagi menjadi beberapa tingkat yaitu SDLB, SMPLB, dan SMALB. Pada struktur kurikulum SLB mata pelajarannya terbagi menjadi 3 (tiga) kelompok yaitu 1). Kelompok A merupakan merupakan program kurikuler yang bertujuan untuk mengembangkan kompetensi sikap, kompetensi pengetahuan, dan kompetensi keterampilan peserta didik

2Undang-Undang Nomor 20 Tahun 2003 tentang Sistem Pendididikan Nasional Pasal 1 Ayat 1

3I Nyoman Bayu Pramartha, "Sejarah Dan Sistem Pendidikan Sekolah Luar Biasa Bagian A Negeri Denpasar Bali” Jurnal Historia, Vol. 3, No.2, 2015, H. 68.; Lihat juga Lena Yanti Br. Pulungan, Niswanto, Yusrizal, Pengembangan Kompetensi Profesional Guru Program Khusus Pada SDLB Negeri Banda Aceh, dalam Jurnal Administrasi Pendidikan Vol. 5, No. 3 (2017), h. 7-8; dan Lihat juga Lena Yanti, Pengembangan Kompetensi Profesional Guru Program Khusus (Konsep dan Teori), (Banda Aceh: Bandar Publishing, 2017), h. 18-19; lihat juga Dian, Ayuningtyas, dkk. Pendidikan Inklusi dalam Pembelajaran Beyond Centers and Circle Time (BCCT) di Paud Terpadu Griya Ceriya Banda Aceh. Meulaboh: STAIN Teungku Dirundeng. 2019, h. 1-5. 
sebagai dasar dan penguatan kemampuan dalam kehidupan bermasyarakat, berbangsa, dan bernegara yang muatan dan acuannya dikembangkan oleh pusat. 2). Kelompok B merupakan program kurikuler yang bertujuan untuk mengembangkan kompetensi sikap, kompetensi pengetahuan, dan kompetensi keterampilan peserta didik terkait lingkungan dalam bidang sosial, budaya, dan seni yang muatan dan acuannya dikembangkan oleh pusat dan dapat dilengkapi dengan muatan lokal. Muatan lokal dapat berupa mata pelajaran yang berdiri sendiri. 3). Kelompok $\mathrm{C}$ berupa program kebutuhan khusus yang diberikan sesuai dengan kekhususan peserta didik. Program Kebutuhan Khusus untuk tunanetra, tunarungu, tunagrahita, tunadaksa, dan autis. Pada kelompok A terdapat salah satunya pelajaran Bahasa Indonesia. ${ }^{4}$

Mata pelajaran Bahasa Indonesia merupakan ilmu pengetahuan yang harus diampuh oleh peserta didik untuk menumbuhkan dan mengembangkan keterampilanketerampilan berbahasa. Selain itu dengan adanya mata pelajaran Bahasa Indonesia peserta didik dapat mencintai, menghargai, dan melestarikan bahasa, terutama bahasa Indonesia. Ruang lingkup Bahasa Indonesia mencakup aspek keterampilan berbahasa, mendengar/ menyimak, berbicara, membaca, dan menulis. ${ }^{5}$

Salah satu dari kelima aspek tersebut yaitu membaca faktor penting dalam sebuah

4Peraturan Direktur Jenderal Pendidikan Dasar dan Menengah No: 10/D/KR/2017 Tanggal: 4 April 2017 tentang Struktur Kurikulum, Kompetensi Inti-Kompetensi Dasar, dan Pedoman Implementasi Kurikulum 2013 Pendidikan Khusus.

5Ria Hidayati, Modul Permainan Reka Bentuk Blok Bagi Kemahiran Interaksi Sosial dan Komunikasi Murid Autisme Menggunakan Pendekatan Applied Behavior Analysis (ABA), (Banda Aceh: Bandar Publishing, 2019), h. 18. proses pembelajaran di sekolah. Membaca juga merupakan salah satu pintu utama untuk dapat mengakses pengetahuan dan informasi. Membaca adalah proses yang dilakukan serta dipergunakan oleh pembaca untuk memperoleh pesan yang hendak disampaikan oleh penulis melalui media kata-kata atau bahasa tulis. Jadi dengan membaca, siswa dapat memperoleh pengetahuan yang disediakan penulis. Semakin sering seorang siswa membaca, maka pengetahuan dan wawasan yang dimilikinya akan semakin luas. Hal ini dapat mempengaruhi proses belajar dan pola pikir siswa yang bersangkutan. Kebiasaan membaca yang dilakukan oleh seseorang ditentukan oleh berbagai faktor, salah satunya minat. Minat merupakan faktor internal yang mempengaruhi seseorang untuk berbuat sesuatu, salah satunya membaca. Minat baca merupakan salah satu kunci penting bagi seseorang untuk memperoleh ilmu pengetahuan dan informasi. ${ }^{6}$ Untuk mengembangkan sekolah sebagai organisasi pembelajaran, Kementerian Pendidikan dan Kebudayaan mengembangkan Gerakan Literasi Sekolah (GLS). GLS adalah upaya menyeluruh yang melibatkan semua warga sekolah (guru, peserta didik, orang tua/ wali murid) dan masyarakat, sebagai bagian dari ekosistem pendidikan. GLS memperkuat gerakan penumbuhan budi pekerti sebagaimana dituangkan dalam Peraturan Menteri Pendidikan dan Kebudayaan Nomor 23 Tahun 2015. Salah satu kegiatan di dalam gerakan tersebut adalah "kegiatan 15 menit membaca buku nonpelajaran sebelum waktu belajar dimulai”. Kegiatan ini

6Cut Putro Yuliana, dkk, Manajemen Kinerja Guru Pustakwan dalam Pemberdayaan Perpustakaan Sekolah Pada SMAN 2 Meulaboh, dalam LIBRIA, Vol. 11, No. 1,Juni 2019, hlm. 52-53.

Efektivitas Gerakan Literasi 15 Menit ..., | 145 
dilaksanakan untuk menumbuhkan minat baca peserta didik serta meningkatkan keterampilan membaca agar pengetahuan dapat dikuasai secara lebih baik. Materi baca berisi nilai-nilai budi pekerti, berupa kearifan lokal, nasional, dan global yang disampaikan sesuai tahap perkembangan peserta didik. $^{7}$

Namun, Gerakan literasi di sekolah belum berjalan lancar. Baik di sekolah umum, maupun Sekolah Luar Bisas. seseorang anak mustahil mempunyai kegemaran membaca jika tidak pernah membiasakan budaya membaca. Oleh karena itu, sangat penting peran guru dalam membimbing anaknya untuk rajin membaca. Berdasarkan latar belakang masalah tersebut, peneliti ingin melihat apakah Gerakan Literasi, terutama Gerakan 15 menit membaca efektif digunakan untuk menumbuhkan minat membaca pada siswa di Sekolah Luar Biasa, terutama anak Autis?. Untuk itu, melalui penelitian ini, maka peneliti tertarik untuk melakukan pengamatan lebih lanjut melalui penelitian penelitian tindakan ini untuk mengetahui Efektivitas Gerakan Literasi 15 Menit Membaca dalam Menumbuhkan Minat Baca pada Siswa Autis Kelas IV Mata Pelajaran Bahasa Indonesia pada Materi Teks Cerita Narasi di SLB TNCC Banda Aceh". Diharapkan melalui penelitian tindakan ini pula akan dapat gambaran sejauh mana keefektivan gerakan literasi 15 Menit membaca dalam menumbuhkan minat baca pada siswa Autis kelas IV Mata Pelajaran Bahasa Indonesia pada Materi Teks Cerita Narasi.

7Pangesti Wiedarti, dkk. Desain Induk Gerakan Literasi Sekolah, (Jakarta: Direktorat Jenderal Pendidikan Dasar dan Menengah Kementerian Pendidikan dan Kebudayaan, 2016), h. 1.

\section{LANDASAN TEORI}

\section{Gerakan Literasi Sekolah}

Gerakan Literasi Sekolah (GLS) merupakan suatu usaha atau kegiatan yang bersifat partisipatif dengan melibatkan warga sekolah (Peserta Didik, Guru, Kepala Sekolah, Tenaga Kependidikan, Pengawas Sekolah, Komite Sekolah, Orang Tua/Wali Murid Peserta Didik), Akademisi, Penerbit, Media Massa, Masyarakat (Tokoh Masyarakat yang dapat merepresentasikan keteladanan, dunia usaha, dan lain sebagainya), dan pemangku kepentingan di bawah koordinasi Direktorat Jenderal Pendidikan Dasar dan Menengah Kementerian Pendidikan dan Kebudayaan. GLS adalah gerakan sosial dengan dukungan kolaboratif berbagai elemen. Upaya yang ditempuh untuk mewujudkannya berupa pembiasaan membaca peserta didik. Pembiasaan ini dilakukan dengan kegiatan 15 menit membaca (guru membacakan buku dan warga sekolah membaca dalam hati, yang disesuaikan dengan konteks atau target sekolah). Ketika pembiasaan membaca terbentuk, selanjutnya akan diarahkan ke tahap pengembangan, dan pembelajaran (disertai tagihan berdasarkan Kurikulum 2013). Variasi kegiatan dapat berupa perpaduan Desain Induk Gerakan Literasi Sekolah pengembangan keterampilan reseptif maupun produktif. ${ }^{8}$

Gerakan Literasi Sekolah memiliki tujuan utama menjadikan peserta didik sebagai seseorang yang literat. Literat sendiri dapat diartikan sebagai sebuah kemampuan memahami dan mengaplikasikan ragam teks dalam kehidupan bermasyarakat. Literat

8Pangesti Wiedarti. dkk. Desain Induk Gerakan Literasi Sekolah, (Jakarta: Direktorat Jenderal Pendidikan Dasar dan Menengah Kementerian Pendidika dan Kebudayaan, 2016), h. 7. 
menjadikan seseorang bertindak sesuai dengan pengetahuan dan kemampuan yang dimiliki berdasarkan pemahaman terhadap bacaan. Selain itu, GLS juga memperkuat gerakan penumbuhan budi pekerti peserta didik yang dituangkan dalam Peraturan Menteri Pendidikan dan Kebudayaan Nomor 23 tahun 2015.9 Praktik-praktik yang baik dalam gerakan literasi sekolah menekankan prinsip-prinsip yaitu: Pertama, Perkembangan literasi berjalan sesuai tahap perkembangan yang dapat diprediksi; Kedua, Program literasi yang baik bersifat berimbang; Ketiga, Program literasi terintegrasi dengan kurikulum; Keempat, Kegiatan membaca dan menulis dilakukan kapanpun; Kelima, Kegiatan literasi mengembangkan budaya lisan; dan Keenam, Kegiatan literasi perlu mengembangkan kesadaran terhadap keberagaman.

\section{Strategi Membangun Budaya Literasi Sekolah}

Agar sekolah mampu menjadi garis depan dalam pengembangan budaya literasi, Beers, dkk. dalam buku A Principal's Guide to Literacy Instruction, menyampaikan beberapa strategi untuk menciptakan budaya literasi yang positif di sekolah diantaranya ialah: 1) Mengkondisikan lingkungan fisik ramah literasi; 2) Mengupayakan lingkungan sosial dan afektif sebagai model komunikasi dan interaksi yang literat; dan 3) Mengupayakan sekolah sebagai lingkungan akademik yang literat. Aspek-aspek tersebut adalah karakteristik penting dalam pengembangan budaya literasi di sekolah. Dalam pelaksanaannya, sekolah dapat

9Novita Dessy Eriyani, Pengaruh Gerakan Literasi Sekolah Terhadap Keterampilan Menulis Teks Deskripsi, (Surakarta: Universitas Sebelas Maret), h. 3. mengadaptasinya sesuai dengan situasi dan kondisi sekolah. Guru dan pimpinan sekolah perlu bekerja sama untuk mengimplementasikan strategi tersebut. ${ }^{10}$

Tim literasi sekolah merupakan tulang punggung yang perlu terus diperkuat dan dikembangakan. Pembentukan tim literasi sekolah merupakan tahapan awal yang harus di rencanakan oleh sekolah agar kegiatan gerakan literasi sekolah dapat berjalan dengan baik. Salah satu tujuan yang paling penting dari pelatihan staf untuk pembentukan TLS adalah untuk menjalankan peran mereka sebagai fasilitator yang membantu siswa agar terhubung secara emosi dan pikiran dengan buku.

Alternatif yang dapat digunakan dalam pembentukan tim literasi sekolah diantaranya yaitu Kepala sekolah melakukan pengamatan dengan mencermati para guru yang dirasa dapat menumbuhkembangkan literasi di sekolah. selanjutnya dengan kewenangannya Kepala Sekolah memilih dan menetapkan Tim Literasi sekoLah yang terdiri atas minimal satu guru bahasa, satu guru mata pelajaran lain, serta satu petugas perpustakaan/ tenaga kependidikan. Selanjutnya tim literasi sekolah yang telah terbentuk ditugasi dengan surat keputusan atau surat penugasan resmi. Kemudian guru yang menjadi tim literasi sekolah diberi kesempatan mengikuti pelatihan atau workshop literasi sebagai wujud pengembangan profesional tentang literasi.

Dalam kedudukannya, tim literasi sekolah mempunyai beberapa tugas pokok dan fungsi untuk menumbuhkembangkan gerakan

10Pangesti Wiedarti, dkk. Desain Induk Gerakan Literasi Sekolah, (Jakarta: Direktorat Jenderal Pendidikan Dasar dan Menengah Kementerian Pendidikan dan Kebudayaan, 2016), h. 11-15.

Efektivitas Gerakan Literasi 15 Menit ..., | 147 
literasi di sekolah. Tugas minimal yang harus dilaksanakan tim literasi sekolah diantaranya adalah merencanakan, melaksanakan, melaporkan, dan melakukan asesmen serta mengevaluasi pelaksanaan gerakan literasi sekolah. Untuk melihat keberhasilan gerakan literasi sekolah yang telah dilaksanakan dapat diukur dengan beberapa indikator, pertama; gerakan membaca menjadi aktivitas keseharian seluruh warga sekolah. Dalam mengukur keberhasilan gerakan literasi sekolah dapat dilihat dari bagaimana gerakan membaca dilaksanakan, dimana aktivitas membaca menjadi aktivitas keseharian di sekolah. Kedua; terbentuknya komunitas siswa membaca. Ketiga; publikasi tulisan hasil karya literasi siswa dan guru. Keempat; meningkatnya dukungan orangtua dan masyarakat terhadap gerakan literasi sekolah. ${ }^{11}$

\section{Membaca dan Minat Baca}

Membaca adalah suatu interpretasi simbol - simbol tertulis atau membaca adalah menangkap makna dari serangkaian simbol - simbol. Menurut Kridalaksana dalam Fajar Rachmawati membaca adalah memahami tulisan dalam bentuk urutan lambanglambang grafis dan perubahannya menjadi wicara bermakna dalam bentuk pemahaman diam -diam atau pengujaran keras-keras. Membaca menurut Tarigan adalah salah satu proses yang dilakukan serta dipergunakan oleh pembaca untuk memperoleh pesan yang hendak disampaikan oleh penulis melalui media kata atau bahasa lisan, sehingga membaca dapat

11Hanafiati Nur Istiqomah, Implementasi Gerakan Literasi Sekolah (Studi Evaluasi tentang Gerakan Literasi Sekolah di SMPN 2 Taragong Kidul, (Bandung: Universitas Pendidikan Indonesia), h. 6. diartikan sebagai mengidentifikasi simbolsimbol dan mengasosiakannya dengan makna. Kamus Besar Bahasa Indonesia bahwa membaca adalah mengeja atau melafalkan apa yang tertulis. Sabarti Akhadiah dkk. mengungkapkan bahwa membaca merupakan suatu kesatuan kegiatan seperti mengenali huruf dan kata-kata, menghubungkannya dengan bunyi serta maknanya, serta menarik kesimpulan mengenai maksud jawaban. Kholid A. $\mathrm{H}$ dan Lilis $\mathrm{S}$ mengemukakan membaca adalah mengemukakan atau membunyikan rangkaian lambang- lambang bahan tulis yang dilihatnya dari huruf menjadi kata, kemudian menjadi frasa, kalimat dan seterusnya. Membaca merupakan rangkaian huruf-huruf yang dibunyikan sehingga memiliki makna. Berdasarkan beberapa pengertian di atas dapat disimpulkan bahwa membaca adalah suatu aktifitas membunyikan rangkaian lambanglambang berupa huruf yang dihubungkan menjadi kata yang memiliki suatu makna tersendiri.

Membaca adalah salah satu tuntutan dalam kehidupan masyarakat modern. Melalui kegiatan membaca kita dapat mengetahui dan menguasai berbagai hal. Tujuan membaca menurut Nurhadi bahwa tujuan membaca akan mempengaruhi pemerolehan pemahaman bacaan.Jikasemakinkuattujuanseseorang dalam membaca maka semakin tinggi pula kemampuan orang itu dalam memahami bacaannya. Tujuan membaca menurut Blanton dkk dan Irwin dalam Farida Rahim, membaca sebagai berikut : 1) Kesenangan; 2) Menyempurnakan startegi tertentu; 3) Mempergunakan strategi tertentu; 4) Memperbaharui pengetahuan tentang suatu topik; 5) Mengaitkan informasi baru 
dengan informasi yang telah diketahuinya; 6) Memperoleh informasi untuk laporan lisan atau tertulis; 7) Mengkonfirmasi atau menolak prediksi; ndan 8) Menampilkan suatu eksperimen atau mengaplikasikan suatu informasi yang diperoleh dari suatu teks dalam beberapa cara lain dan mempelajari tentang struktur teks, menjawab pertanyaan pertanyaan yang spesifik. $^{12}$

$$
\text { Setiap orang }
$$

mempunyai

kecenderungan untuk selalu berhubungan dengan sesuatu yang dianggapnya memberikan kesenangan dan kebahagiaan. Dari perasaan senang tersebut timbul keinginan untuk memperoleh dan mengembangkan apa yang telah membuatnya senang dan bahagia. Slameto mengatakan bahwa minat adalah kecenderungan yang tetap untuk memperhatikan dan mengenang beberapa kegiatan. Kegiatan yang diminati sesorang diperhatikan terus menerus yang disertai dengan rasa senang. Minat selalu diikuti dengan perasaan senang dan dari situ diperoleh kepuasan. Minat besar pengaruhnya terhadap belajar, karena bila bahan pelajaran yang dipelajari tidak sesuai dengan minat siswa, siswa tidak akan belajar dengan sebaik-baiknya. Bahan pelajaran yang menarik minat siswa, lebih mudah dipelajari karena minat menambah dorongan untuk belajar.

Minat menurut Hurlock merupakan sumber motivasi yang mendorong orang untuk melakukan apa yang mereka inginkan bila mereka bebas memilih. Bila mereka

12 Hasna Nur Halimah Sudwiyanto, "Peningkatan Keterampilan Membaca Pemahaman Pada Literasi Informasi Iklan Menggunakan Metode Kooperatif Integrated Reading and Composition (CIRC) Pada Peserta Didik Kelas V SD Negeri Nyaen 1 Tahun Ajaran 2019/2020”, e-Thesis. (Yogyakarta:Fakultas Ilmu Pendidikan Universitas Negeri Yogyakarta, 2020) h.7. melihat sesuatu akan menguntungkan, mereka merasa berminat. Hal ini akan mendatangkan kepuasan. Jadi dapat disimpulkan bahwa minat merupakan suatu sikap batin dari dalam diri seseorang yang merupakan suatu perhatian khusus terhadap suatu hal tertentu yang tercipta dengan penuh kemauan dan perasaan senang yang timbul dari dorongan batin seseorang. Minat dapat dikatakan sebagai dorongan kuat bagi seseorang untuk melakukan segala sesuatu dalam mewujudkan pencapaian tujuan dan citacita yang menjadi keinginannya. ${ }^{13}$

\section{Autisme}

Autisme adalah gangguan perkembangan yang sangat kompleks yang sejak dahulu menjadi salah satu misteri di dunia kedokteran. Autisme sebenarnya bukan barang baru dan sudah ada sejak lama, namun belum terdiagnosis sebagai autis. Menurut cerita-cerita zaman dulu sering-kali ada anak yang dianggap 'aneh'; anak tersebut sejak lahir sudah menunjukkan gejala yang tidak biasa. Mereka menolak bila digendong, menangis kalau malam dan tidur bila siang hari. Mereka sering-kali bicara sendiri dengan bahasa yang tidak dimengerti oleh orang tuanya. Apabila dalam kondisi marah mereka bisa menggigit, mencakar, menjambak atau menyerang. Kadangkala mereka tertawa sendiri seolah-olah ada yang mengajaknya bercanda. Para orang tua pada saat itu menganggap anak ini tertukar (a changeling) dengan anak peri, sehingga tidak bisa menyesuaikan dengan kehidupan manusia normal, hal tersebut dijabarkan oleh Budhiman

13Meila, Dwi Masfuatun, "Implementasi Program Minat Baca di Sekolah Dasar Golong Yogyakarta", Thesis, Yogyakarta: Fakultas Ilmu Pendidikan, 2020). h. 20.

Efektivitas Gerakan Literasi 15 Menit..., | 149 
dalam Nugraheni S.A. ${ }^{14}$

Pada tahun 1943 seorang psikiater anak yang bernama Leo Kanner menjabarkan dengan sangat rinci gejala-gejala 'aneh' yang ditemukan pada 11 pasien kecilnya. Leo Kanner melihat banyak sekali persamaan gejala pada anak-anak ini, tetapi yang sangat menonjol adalah mereka sangat asyik dengan dirinya sendiri seolah-olah mereka hanya hidup dalam dunianya sendiri. Maka dia memakai istilah 'autis-me' yang artinya hidup dalam dunianya sendiri. Karena ada juga orang dewasa yang menunjukkan gejala 'autisme', maka untuk membedakannya dipakai istilah 'early infantile autism' atau autisme infantil. Dia membuat hipotesis bahwa anak-anak ini kemungkinan menderita gangguan metabolisme yang telah dibawa sejak lahir (inborn error of metabolism). Gangguan metabolisme ini menyebabkan anak terse-but tidak dapat bersosialisasi. Namun pada zaman itu alat kedokteran belum secanggih sekarang sehingga Kanner tidak dapat membuktikan hipotesisnya.

Pada permulaan perang dunia kedua, seorang Yahudi dari Wina melarikan diri dari kejaran Hitler ke Amerika. Dia bernama Bruno Bettelhem dan mengaku pada masyarakat Amerika bahwa ia adalah seorang ahli pendidikan dan psikolog lulusan Universitas Wina dan murid Siegmund Freud. Pada zaman itu Amerika sangat mengagumi kebudayaan Eropa dan sangat mengagumi Siegmund Freud; sehingga Bruno yang mengaku sebagai muridnya langsung diterima

14 Nugraheni S.A, Menguak Belantara Autisme dalam Buletin Psikologi, (Yogyakarta: Universitas Gajah Mada, 2020), h. 9; lihat juga Lena Yanti, Pengembangan Kompetensi Profesional Guru Program Khusus (Konsep dan Teori), (Banda Aceh: Bandar Publishing, 2017), h. 20-21. dan dikagumi oleh kaum intelek Amerika. Baru setelah meninggal karena bunuh diri diketahui bahwa Bruno bukan seorang pendidik maupun psikolog dan tidak pernah menjadi murid Siegmund Freud. Namun pada saat itu Bruno dipercayakan untuk mengelola sebuah asrama untuk anak-anak dengan berbagai gangguan perilaku termasuk beberapa anak dengan gejala autisme dititipkan. ${ }^{15}$

Menurut Yuwono autis merupakan gangguan perkembangan neurobiologis yang sangat komplek dalam kehidupan yang meliputi gangguan pada aspek interaksi sosial, komunikasi dan bahasa, dan perilaku serta gangguan emosi dan persepsi sensori bahkan pada aspek motoriknya. Gejala autis muncul pada usia sebelum 3 tahun. Menurut Mulyati Autis adalah suatu bentuk ketidakmampuan dan gangguan perilaku yang membuat penyandang lebih suka menyendiri. Disamping itu autis juga merupakan suatu gangguan perkembangan fungsi otak yang kompleks dan sangat bervariasi (spektrum). Biasanya, gangguan ini meliputi cara berkomunikasi, berinteraksi sosial dan kemampuan berimajinasi. Penyebab dari autis sebenarnya sudah terjadi sebelum bayi dilahirkan bahkan sebelum vaksinasi dilakukan. Seorang ahli embrio yaitu Patricia Rodier menyebutkan bahwa gejala autis disebabkan karena terjadinya kerusakan jaringan otak. ${ }^{16}$

\section{Bahasa Indonesia}

Zamzani \& Sumaryadi menyatakan

15Menguak Belantara Autisme dalam Buletin Psikologi, (Yogyakarta: Universitas Gajah Mada, 2020), h. 9 .

16 Pratiwi M.I,.” Pengaruh Bermain Peran Mikro Terhadap Perkembangan Bahasa Dan Personal Sosial Anak Autis Di SLB Negeri Semarang". Undergraduate Thesis. (Semarang: Universitas Muhammadiyah Semarang, 2018) h. 8. 
bahwa pengajaran bahasa Indonesia dipandang sebagai sarana, antara lain untuk membakukan ragam-ragam bahasa. Arah pengajaran bahasa Indonesia tersebut tentu saja meliputi .cakupan yang dimulai dari tingkat dasar sampai dengan perguruan tinggi. Untuk itu, perlu kita lihat penggunaan ragambahasa yang dilakukan oleh para mahasiswa kita. Salah satu ragam bahasa yang akan kita lihat adalah penggunaan bahasa resmi. ${ }^{17}$ Bahasa Indonesia merupakan bahasa nasional dan bahasa resmi di Indonesia. Bahasa Nasional adalah bahasa yang menjadi standar di negara Indonesia. Sebagai bahasa nasional, bahasa Indonesia tidak mengikat pemakainya untuk sesuai dengan kaidah dasar. Bahasa indonesia digunakan secara non resmi,santai dan bebas. Dalam pergaulan sehari - hari antar warga yang dipentingkan adalah makna yang disampaikan. Pemakai Bahasa Indonesia dalam konteks Bahasa Nasional dapat menggunakan dengan bebas menggunakan ujarannya baik lisan maupun tulis. Bahasa Indonesia sangat penting dipelajari anak SD/MI karena: a) Sebagai alat untuk mengembangkan kemampuan berkomunikasi dengan lingkungan.

b) Sebagai alat untuk mengembangkan kemampuan intelektual anak. c) Sebagai alat untuk mengembangkan ekspresi anak. d) Sebagai dasar untuk mempelajari berbagai ilmu dan tingkatan pendidikan selanjutnya ${ }^{18}$

\section{Teks Narasi}

17Zamzani dan Sumaryadi, Penggunaan Bahasa Indonesia Dalam Tesis Mahasiswa IKIP Yogyakarta, (Yogyakarta: Cakrawala Pendidikan.1, cet. IV, 1985), h.53.

18Fatimah.S., Peningkatan Hasil Belajar Bahasa Indonesia Tentang Membaca Bacaan Dengan Latihan Membaca Nyaring Pada Siswa Kelas I Madrasah Ibtidaiyah Negeri Medali Puri Mojokerto. Undergraduate Thesis. (Surabaya: UIN Sunan Ampel Surabaya, 2014) h. 5.
Narasi adalah suatu bentuk karangan atau wacana yang mengisahkan atau menceritakan sejelas-jelasnya kepada pembaca atau peristiwa atau kejadian dalam suatu jalinan waktu yang dinamis. Dengan pengisahan peristiwa ini penulis berharap dapat membawa pembaca suatu suasana yang memungkinkannya seperti menyaksikan atau mengalami sendiri peristiwa itu. Narasi terbagi dua yaitu narasi ekspositoris dan narasi sugestif. Perbedaan narasi ekspositoris dan narasi sugestif terlihat

\begin{tabular}{|l|l|}
\hline \multicolumn{1}{|c|}{ Narasi Ekspositoris } & \multicolumn{1}{|c|}{ Narasi Sugestif } \\
\hline \multicolumn{1}{|c|}{ (I) } & \multicolumn{1}{|c|}{ (II) } \\
\hline 1. Memperluas pengetahuan & 1. Memancing daya khayal dan daya stetik \\
2. Menyampaikan informasi & 2. Menyampaikan suatu makna atau amanat \\
faktualmengenai suatu hal atau peristiwa & $\begin{array}{l}\text { tertentu yang diramu dalam format } \\
\text { kesastraan }\end{array}$ \\
3. Menyajikan kehidupan tokoh dari sisi & 3. Menyajikan secara lengkap kehidupan \\
yang dapat diamati & lahiriah dan bathiniah tokoh-tokoh secara \\
4. Menggunakan penalaran untuk & mendalam \\
kesepakatan nasional & 4. Menggunakan penalaran sebagai alat \\
5. Memiliki tingkat subjektivitas yang relatif & untuk menyampaikan makna sehingga \\
rendah & kalau perlu penalaran dapat dilanggar \\
6. Menggunakan bahasa yang lebih bersifat & 5. Memiliki subjektivitas yang tinggi \\
informatif dengan penekanan pada & 6. Menggunakan bahasa yang bersifat \\
pemakaian kata-kata denotatif & figurative dengan penekanan pada \\
& pemakaian kata-kata konotatif \\
\hline
\end{tabular}

Teks narasi adalah suatu karangan cerita yang menyajikan serangkaian peristiwa kejadian dan disusun secara kronologis sesuai dengan urutan waktunya. Peristiwa itu bisa benar benar terjadi, tapi bisa juga hanya khayalan saja. Umumnya karangan atau teks narasi diciptakan dengan tujuan menghibur pembacanya dengan pengalaman estetis melalui kisah dan cerita, baik fiksi maupun nonfiksi. ${ }^{19}$ Karangan narasi memiliki struktur karena terdiri atas bagian-bagian yang secara fungsional berkaitan satu sama lain. Komponen yang membentuk struktur tergantung pada macam narasinya, narasi ekspositoris atau narasi sugestif. Khusus narasi sugestif, komponen-

19Kemendikbud, Teks Narasi dan LIterasi Buku Fiksi-NonFiksi (Cas Dari Cerita dan Buku). (Kalimantan Selatan: Direktorat Jenderal PAUD dan Pendidikan Masyarakat, 2018) h.1.

Efektivitas Gerakan Literasi 15 Menit ..., | 151 
komponen pembentuk strukturnya adalah alur (plot), perbuatan, perwatakan, penokohan, latar (setting) dan sudut pandang. ${ }^{20}$

\section{METODE PENELITIAN}

Metode penelitian yang digunakan dalam penelitian ini adalah penelitian kualitatif. Penelitian kualitatif menghasilkan data deskriptif berupa kata-kata. Data yang dianalisis di dalamnya berbentuk deskriptif dan tidak berupa angka-angka seperti halnya pada penelitian kuantitatif. ${ }^{21}$ Menurut Arikunto dalam Windarett Mardianinta (2016) penelitian kualitatif dimaksudkan untuk mengumpulkan informasi mengenai status suatu gejala yang ada, yaitu keadaan gejala menurut apa adanya pada saat penelitian itu dilakukan. Oleh karena itu, penelitian kualitatif mampu mengungkap fenomenafenomena pada suatu subjek yang ingin diteliti secara mendalam. ${ }^{22}$ Penelitian ini dilakukan di SLB TNCC Banda Aceh. Subjek penelitian merupakan siswa yang akan diteliti dalam penelitan. Adapun yang menjadi subjek penelitian disini adalah siswa kelas IV Autis SLB TNCC Banda Aceh, tahun ajaran 2020/2021 yang berjumlah 2 orang siswa. Teknik pengumpul data dilakukan dengan cara observasi, wawancara, dan dokumentasi.

20Hieronimus T.K. Very Much, S.Pd, "Meningkatkan Kemampuan Menulis Karangan Narasi Melelui Pendekatan Kontekstual Dengan Inspirator Lingkungan Sekolah Siswa Kelas Vii Smp Negeri 1 Sano Nggoang, Manggarai Barat Tahun Pelajaran 2016/2017" Jurnal Jime, Vol. 3, No.1, 2017, 303-304.

21Rahmad Syah Putra, Strategi Peningkatan Mutu Pendidikan pada SMA Negeri 3 Meulaboh Kecamatan Johan Pahlawan Kabupaten Aceh Barat, dalam Jurnal Administrasi Pendidikan, Vol. 5 Nomor 3 Agustus 2017, 163.

22Windarett Mardianinta, Perilaku Prososial Pada Scooterist Vespa Ekstrim Di Semarang". Other Thesis, (Semarang: Unika Soegijapranata, 2016), h. 44.
Teknik observasi digunakan penulis dalam rangka mengamati guru dalam proses belajar mengajar dalam rangka untuk meningkatkan mutu pendidikan. Selanjutnya, dokumentasi diperlukan untuk melihat berbagai catatancatatan yang ada relevansinya dengan penulisan laporan penelitian ini. Selanjutnya, wawancara dilakukan untuk mengumpulkan data melalui informasi dari pihak terkait dan terlibat dalam pelaksanaan. Sementara Teknik Analisis Data dikumpulkan lalu dianalisis secara kualitatif dengan tahapan diantaranya ialah: (1) Reduksi data, yaitu menyederhanakan data yang telah dikumpulkan yang sesuai dengan rumusan masalah penelitian. (2) Penyajian Data, yaitu data yang telah diperoleh melalui teknik pengumpulan data akan diorganisasikan, disusun dalam bentuk tabel, sehingga akan mudah difahami. (3) Triangulasi, yakni mengecek kredibilitas data dari berbagai teknik pengumpulan data dan berbagai sumber data. Teknik triangulasi merupakan teknik pemeriksaan keabsahan data yang memanfaatkan sesuatu yang lain, diluar data itu untuk keperluan pengecekan atau sebagai pembanding terhadap data yang diperoleh. dan (4) Verifikation serta Penarikan Kesimpulan.

\section{HASIL PENELITIAN}

\section{A. Hasil Penelitian}

Penelitian ini dilaksanakan di SLB TNCC Banda Aceh pada kelas IV semester ganjil tahun pelajaran 2020/2021 pada materi "Teks Cerita Narasi”. Sekolah ini terletak di Jl. Rajawali, Kp. Kramat, Banda Aceh. Penelitian ini dilaksanakan senin dan rabu disesuaikan dengan mata pelajaran 
bahasa Indonesia ditanggal 5 Oktober 2020 dan 7 Oktober 2020. Mula-Mula guru mempersiapkan berbagai bahan dan indikator dalam melakukan penilaian siswa, diantaranya ialah sebagai berikut: tersebut. Dari beberapa tahapan yang dilakukan, menunjukkan pula bahwa terjadi perubahan yang signifikan bagi siswa autis dalam membaca teks narasi. Hal ini terlihat jelas berdasarkan siklus

Tabel 1. Penilaian Keefektifan Minat Baca

\begin{tabular}{|c|l|c|c|c|}
\hline \multirow{2}{*}{ No. } & \multicolumn{1}{|c|}{ Deskripsi } & \multirow{2}{*}{ Frekuensi } & \multicolumn{2}{|c|}{ Penilaian } \\
\cline { 3 - 5 } & & & Tuntas & Tidak Tuntas \\
\hline 1. & Ketepatan intonasi dalam bacaan & 2 & & \\
\hline 2. & Kejelasan artikulasi dalam membaca & 2 & & \\
\hline 3. & Pemahaman makna isi bacaan & 2 & & \\
\hline 4. & Menceritakan kembali isi cerita & 2 & & \\
\hline
\end{tabular}

Mengacu pada indikator di yang dilakukan oleh guru pada beberapa atas pula, kemudian guru melakukan tahap pada tabel di bawah ini:

\begin{tabular}{|c|c|c|c|c|c|c|c|}
\hline \multirow{2}{*}{ No. } & \multirow{2}{*}{ Nama Siswa } & \multicolumn{2}{|c|}{ Pra Penilaian } & \multicolumn{2}{c|}{$\begin{array}{c}\text { Penilaian Tahap } \\
\text { Pertama }\end{array}$} & \multicolumn{2}{c|}{$\begin{array}{c}\text { Penilaian Tahap } \\
\text { Kedua }\end{array}$} \\
\cline { 3 - 8 } & & Tuntas & $\begin{array}{c}\text { Tidak } \\
\text { Tuntas }\end{array}$ & Tuntas & $\begin{array}{c}\text { Tidak } \\
\text { Tuntas }\end{array}$ & Tuntas & $\begin{array}{c}\text { Tidak } \\
\text { Tuntas }\end{array}$ \\
\hline 1. & Ardiyan & - & 50 & - & 55 & 68 & - \\
\hline 2. & $\begin{array}{c}\text { Wan Raziqi } \\
\text { Ansyahra }\end{array}$ & - & 50 & 65 & - & 69 & - \\
\hline
\end{tabular}

kegiatan penelitian tindakan ini dengan 3 (tiga) tahapan dimulai dari Pra Penilaian, Penilaian Tahap Pertama, dan Penilaian Tahap Kedua. Berdasarkan hasil penelitian tindakan yang dilakukan pula, terdapat hasil bahwa Gerakan 15 Menit Membaca sangat signifikan dalam proses belajar membaca pelajaran Bahasa Indonesia untuk siswa autis kelas IV SDLB TNCC Banda Aceh, dan dengan menggunakan program Gerakan 15 Menit membaca yang dilakukan oleh guru sebelum Proses Belajar Mengajar (PBM) pula, siswa dapat mengetahui isi bacaan dan menceritakan kembali makna terkadung dalam bacaan
Tabel. 1 Siklus Tahapan Program

Berdasarkan Tabel di atas terlihat bahwa terdapat perbedaan antara Pra Siklus, dengan Siklus Pertama dan Siklus Kedua. Siswa Autis terlihat pengaruh yang signifikan terhadap proses belajar membaca melalui Gerakan 15 Menit membaca yang diprogramkan guru, dan dengan merujuk pada beberapa indikator penilaian di atas pula, diperoleh hasil bahwa siswa autis sangat efektif dalam membaca melalui proses Gerakan 15 Menit Membaca yang diprogramkan oleh Guru Bahasa Indonesia SDLB TNCC Banda Aceh. Ketuntasan siswa dalam membaca pundapat dicapai pada tahap tuntan. Adapun tingkat ketuntasan siswa dapat 
dilihat pula pada tabel berikut ini:

Grafik 1. Tingkat Efektifitas Program Gerakan 15 Menit Membaca

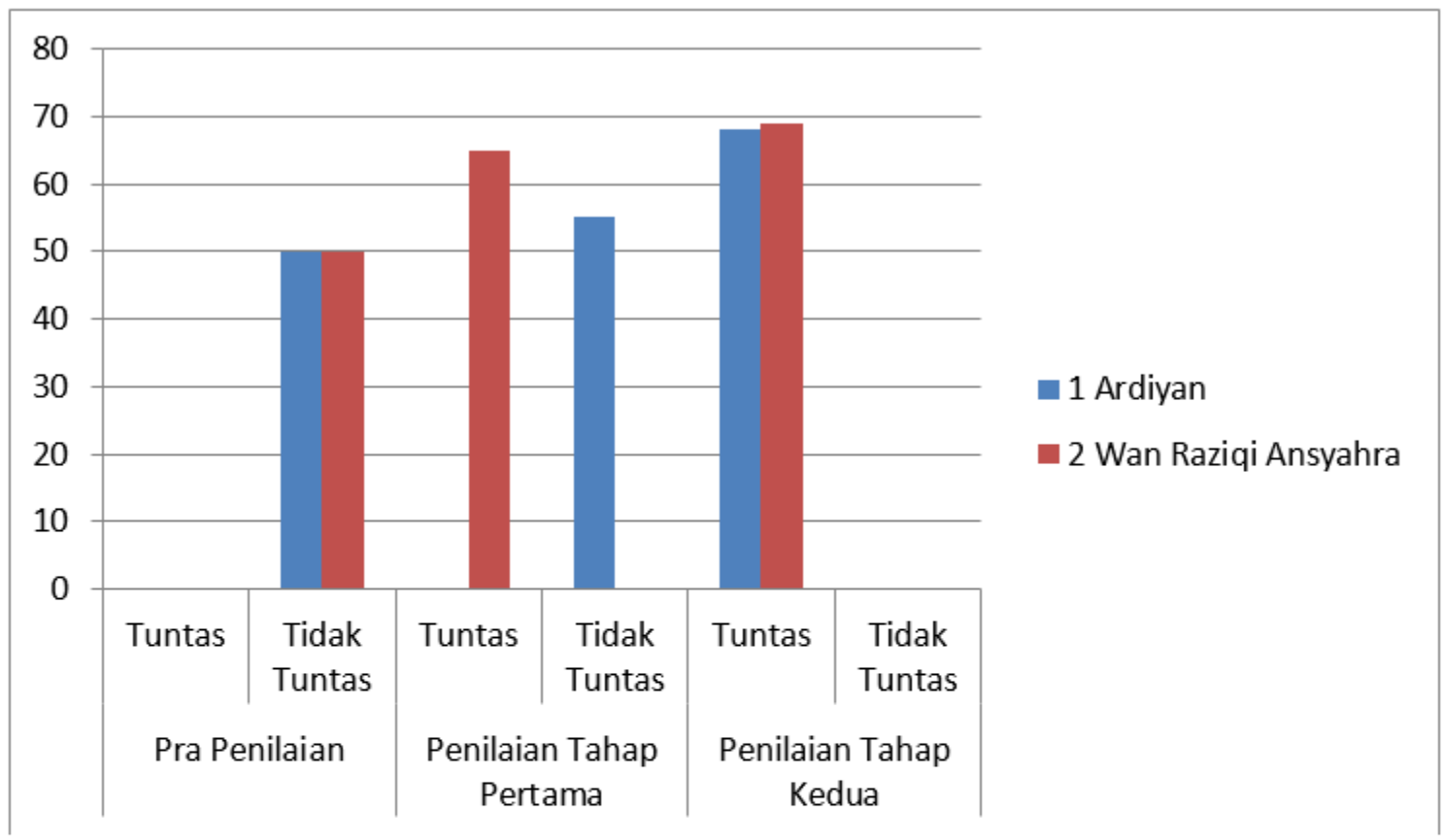

Tabel 2. Hasil Penilaian Keefektifan Minat Baca

\begin{tabular}{|l|l|c|c|}
\hline \multirow{2}{*}{ No. } & \multicolumn{2}{|c|}{ Nama Siswa } & \multicolumn{2}{|c|}{ Penilaian } \\
\cline { 3 - 4 } & & Tuntas & Tidak Tuntas \\
\hline 1. & $\begin{array}{c}\text { Ardiyan } \\
\text { Chart Area }\end{array}$ & $\sqrt{ }$ & \\
\hline 2. & Wan Raziqi Ansyahra & $\sqrt{ }$ & \\
\hline
\end{tabular}

(Sumber: SLB TNCC Banda Aceh)

Berdasarkan data di atas dapat hingga siswa senang.

disimpulkan bahwa Gerakan Literasi 15 menit sebelum Proses Belajar Mengajar sangat efektif dilakukan untuk menumbuhkan minat baca siswa pada autis kelas IV. Hal ini dilihat dari hasil ketuntasan indikator keefektifan minat baca. Hanya saja dalam proses implementasiannya guru perlu kesabaran dalam implementasi. Sebab, anak-anak yang dihadapi sangat istimewa dan perlu suatu proses khusus pula yang dilakukan secara berulang-ulang
Berdasarkan hasil wawancara dengan guru di SLB TNCC pada tanggal 15 September 2020 diperoleh bahwa Gerakan literasi sekolah malaui kegiatan 15 menit sebelum Proses Belajar Mengajar (PBM) sangat efektif untuk dijadikan pembiasaan di kelas. Sebab ,Anak autis sangat unik dan khas. Kekhasan pada anak autis menjadi daya tarik sendiri bagi orang yang ada di sekitarnya. Tidak semua orang dapat memahami tuturan anak autis. Proses 
pembelajaran yang diterima anak autis di sekolah ternyata berlaku sama untuk anak yang lain meskipun kondisi atau keadaannya berbeda. Maksudnya materi yang diterima sama meskipun cara menerimanya berbeda. Sebagian orang kurang memahami tuturan anak autis. Ocehan yang terkadang kurang bermakna dianggap aneh atau lucu. ${ }^{23}$

Berdasarkan hasil penelitian di atas pula, menurut hemat penulis bahwa apabila mengacu pada Peraturan Menteri Pendidikan dan Kebudayaan Republik Indonesia Nomor 23 Tahun 2015, Gerakan 15 Menit Membaca sangat efektif digunakan sebagai sarana pendukung dalam rangka untuk menumbuhkan semangat belajar sebelum pelajaran dimulai. Oleh sebab itu, terutama bagi anak Autisme terutama memperkenalkan bacaan yang ada seperti misalnya media kliping bergambar yang dapat menarik perhatian peserta didik, sehingga mereka tidak lari keluar kelas. Kemampuan perserta didik membaca, menulis dan mengkritisi sebuah bacaan dapat dilihat secara lisan. Karya yang mereka buat, merupakan bukti bahwa mereka mengerti tugas yang disampaikan guru.

\section{B. Pembahasan}

Seseorang dikatakan berminat bila mempunyai kemauan dan motivasi serta perhatian khusus terhadap suatu hal tertentu, sehigga mempunyai dorongan kuat bagi seseorang untuk melakukan segala sesuatu dalam mewujudkan keinginannya tersebut. Untuk menumbuhkan minat baca pada siswa tidak perlu memerlukan waktu yang lama, yang harus diperhatikan adalah frekuensi kegiatan

23 Wawancara dengan Guru TNCC Banda Aceh pada 16 September 2020 membacanya. Lamanya waktu yang dihabiskan siswa dalam satu kegiatan membaca bukanlah halyang penting, tapi kegiatan membaca tersebut harus dilakukan secara berulang-ulang dan dilakukan setiap hari. Menurut permendikbud No 23 Tahun 2015 tentang penumbuhan Budi Pekerti, tidak perlu juga dimaknai sebagai durasi ideal untuk membaca. Lima belas menit adalah waktu minimal untuk membaca. ${ }^{24}$

Buku yang dibaca siswa ketika program 15 menit membaca adalah; pertama buku cerita bergambar, yang bercerita tentang pembiasaan sehari-hari berkaitan dengan perilaku, etika, adab dan kemandirian. Kedua, buku cerita dongeng/legenda, dan ketiga adalah buku yang berkaitan dengan ensiklopedia. Kenapa pada program 15 menit membaca digunakan buku nonteks pelajaran dari pada buku pelajaran? Sebab siswa pasti membaca buku pelajaran sepanjang kegiatan belajar-mengajar di kelas. Harus ada waktu yang diberikan kepada mereka untuk membaca buku selain buku pelajaran. Untuk itulah diadakan program literasi membaca yang bertujuan agar siswa mampu memahami dan mengaplikasikan ragam teks dalam kehidupan bermasyaraat. Literat juga menjadikan seseorang bertindak sesuai pengetahuan dan kemampuan yang dimiliki berdasarkan pemahaman terhadap bacaan serta menumbuhkan budi pekerti peserta didik.

Efektifitas gerakan literasi 15 menit membaca dalam pembelajaran Bahasa Indonesia sangat efektif dilakukan bagi anak autis dan untuk menumbuhkan minat baca siswa diukur dengan Instrumen penilaian

24 Billy Antoro, Gerakkan Literasi Sekolah dari Pucuk Hingga Akar Sebuah Refleksi, (Jakarta: Direktorat Jenderal Pendidikan Dasar dan Menengah Kementerian Pendidikan dan Kebudayaan, 2017), h. 34.

Efektivitas Gerakan Literasi 15 Menit..., | 155 
Keefektifan Minat Baca. Ada empat aspek yang dilihat yaitu: Pertama, ketepatan intonasi dalam bacaan; Kedua, kejelasan artikulasi dalam membaca; Ketiga, pemahaman makna isi bacaan; dan Keempat, menceritakan kembali isi cerita. Hal ini harus didukung pula oleh peran guru dan motivasi siswa dalam membaca. Guru memotivasi siswa untuk memulai membaca apa yang siswa suka, sehingga muncul minat dan kebiasaan membaca. Minat dapat dikatakan sebagai dorongan kuat bagi seseorang untuk melakukan segala sesuatu dalam mewujudkan pencapaian tujuan dan cita-cita yang menjadi keinginannya. Dimana, selain guru yang membacakan cerita, kadang-kadang literasi membaca juga dilakukan oleh anak sendiri. Anak membaca cerita berdasarkan gambar yang ada dalam buku. Anak berimajinasi mengenai gambar yang ada dalam buku. Hal ini merupakan variasi dalam kegiatan membaca. Guru memberikan kebebasan berimajinasi pada anak untuk membaca buku walaupun anak membaca berdasarkan gambar yang ada dalam buku. Ada cerita yang dibacakan guru dan ada juga yang dibacakan siswa. Hal tersebut untuk membuat anak antusias dan konsentrasi memerhatikan bacaan, Dan agar anak tidak bosan atau jenuh sehingga budaya literasi ini dapat dilakukan dua arah atau lebih. Kegiatan membacakan cerita ini akan membuat anak tertarik jika cerita yang dibacakan adalah cerita baru dan belum pernah didengar. Ada juga anak yang suka dengan satu cerita yang telah dibacakan atau diperdengarkan. Bagi anak dengan kondisi ini ia akan meminta untuk dibacakan atau diperdengarkan kembali

\section{PENUTUP}

Berdasarkan hasil penelitian Gerakan Literasi 15 menit membaca sangat efektif dilakukan dalam rangka menumbuhkan minat baca siswa pada anak autis kelas IV di SLB TNCC Banda Aceh, dan dengan meggunakan metode Gerakan Literasi 15 menit membaca pada materi teks cerita narasi dapat disimpulkan bahwa minat baca siswa meningkat signifikan. Hal ini dapat dilihat dari hasil ketuntasan indikator keefektifan minat baca, yang menunjukkan bahwa kedua siswa Autis kelas IV SLB TNCC Banda Aceh termasuk dalam kategori tuntas. Keberhasilan gerakan literasi 15 menit membaca tentunya didukungan oleh peran guru dalam memotivasi siswa dalam hal membaca. Guru memotivasi siswa untuk memulai membaca apa yang siswa suka, sehingga muncul minat dan kebiasaan membaca.

\section{A. Saran}

1. Kepada sekolah yang menerapkan gerakan literasi 15 menit membaca agar menyiapkan sarana dan prasarana sebaik mungkin agar program ini dapat berjalan dengan efektif.

2. Untuk mencapai kualitas minat baca siswa yang maksimal, diharapkan kepada penanggung jawab GLS dan pendidik (guru) lebih kreatif, inovatif, efektif, terampil dan profesional dalam mengajar dan mengelola program serta memberikan kesempatan kepada siswa untuk berperan aktif.

3. Program GLS ini sangat bagus diterapkan di setiap sekolah karena mampu menumbuhkan minat baca siswa sehingga 
akan berpengaruh pada hasil belajar siswa dan tujuan pembelajaran membaca akan tercapai.

\section{DAFTAR PUSTAKA}

Antoro, Billy. Gerakkan Literasi Sekolah dari Pucuk Hingga Akar Sebuah Refleksi. Jakarta: Direktorat Jenderal Pendidikan Dasar dan Menengah Kementerian Pendidikan dan Kebudayaan. 2017.

Ayuningtyas, Dian, dkk. Pendidikan Inklusi dalam Pembelajaran Beyond Centers and Circle Time (BCCT) di Paud Terpadu Griya Ceriya Banda Aceh. Meulaboh: STAIN Teungku Dirundeng. 2019.

Departemen Pendidikan Nasiona. UndangUndang Nomor 20 Tahun 2003 tentang Sistem Pendididikan Nasional Pasal 1 Ayat 1.

Eriyani, Novita Dessy. Pengaruh Gerakan Literasi Sekolah Terhadap Keterampilan Menulis Teks Deskripsi, Surakarta: Universitas Sebelas Maret. 2020.

Helfiana, Mita. Penguasaan Konsep pada Materi Tata Nama Senyawa Melalui Pembelajaran Berbasis Inkuiri Siswa Kelas X SMAN 1 Labuhanhaji. E-Skripsi, Banda Aceh: UIN Ar-Raniry, 2016.

Hidayati, Ria. Modul Permainan Reka Bentuk Blok Bagi Kemahiran Interaksi Sosial dan Komunikasi Murid Autisme Menggunakan Pendekatan Applied Behavior Analysis $(A B A)$. Banda Aceh: Bandar Publishing. 2019.

Istiqomah, Hanafiati Nur. Implementasi Gerakan Literasi Sekolah (Studi Evaluasi tentang Gerakan Literasi Sekolah di SMPN 2 Taragong Kidul, Bandung: Universitas Pendidikan Indonesia. 2018.

Kemendikbud, Teks Narasi dan LIterasi Buku Fiksi-NonFiksi (Cas Dari Cerita dan Buku). Kalimantan Selatan: Direktorat Jenderal PAUD dan Pendidikan Masyarakat. 2018.

Kementerian Pendidikan dan Kebudayaan Republik Indonesia. Peraturan Direktur
Jenderal Pendidikan Dasar dan Menengah No: 10/D/KR/2017 Tanggal: 4 April 2017 tentang Struktur Kurikulum, Kompetensi Inti-Kompetensi Dasar, dan Pedoman Implementasi Kurikulum 2013 Pendidikan Khusus.

M.I., Pratiwi.Pengaruh Bermain Peran Mikro Terhadap Perkembangan Bahasa Dan Personal Sosial Anak Autis Di SLB Negeri Semarang". Undergraduate thesis. Semarang: Universitas Muhammadiyah Semarang. 2018

Mardianinta, Windarett. Perilaku Prososial Pada Scooterist Vespa Ekstrim Di Semarang”. E-Thesis. Semarang: Unika Soegijapranata. 2016.

Meila, Dwi Masfuatun, "Implementasi Program Minat Baca di Sekolah Dasar Golong Yogyakarta", e-Thesis, Yogyakarta: Fakultas Ilmu Pendidikan. 2020.

Pramartha, I Nyoman Bayu. Sejarah Dan Sistem Pendidikan Sekolah Luar Biasa Bagian A Negeri Denpasar Bali. Jurnal Historia, Vol. 3 Nomor 2 Agustus 2015, 68.

Pulungan, Lena Yanti Br. Pengembangan Kompetensi Profesional Guru Program Khusus Pada SDLB Negeri Banda Aceh. Jurnal Administrasi Pendidikan Vol. 5, Nomor 3 Agustus 2017. 7-8.

Putra, Rahmad Syah. Strategi Peningkatan Mutu Pendidikan pada SMA Negeri 3 Meulaboh Kecamatan Johan Pahlawan Kabupaten Aceh Barat, dalam Jurnal Administrasi Pendidikan, Vol. 5 Nomor 3 Agustus 2017, 163.

S., Fatimah. Peningkatan Hasil Belajar Bahasa Indonesia Tentang Membaca Bacaan dengan Latihan Membaca Nyaring pada Siswa Kelas I Madrasah Ibtidaiyah Negeri Medali Puri Mojokerto. Undergraduate Thesis. Surabaya : UIN Sunan Ampel Surabaya. 2014 ..

S.A, Nugraheni. Menguak Belantara Autisme dalam Buletin Psikologi. Yogyakarta: Universitas Gajah Mada, 2020.

Sudwiyanto, Hasna Nur Halimah . Peningkatan Keterampilan Membaca Pemahaman Pada 
Literasi Informasi Iklan Menggunakan Metode Kooperatif Integrated Reading and Composition (CIRC) Pada Peserta Didik Kelas V SD Negeri Nyaen 1 Tahun Ajaran 2019/2020, e-Thesis. Yogyakarta: Fakultas Ilmu Pendidikan Universitas Negeri Yogyakarta. 2020,

Very Much,Hieronimus T.K.. Meningkatkan Kemampuan Menulis Karangan Narasi Melelui Pendekatan Kontekstual Dengan Inspirator Lingkungan Sekolah Siswa Kelas VII SMP Negeri 1 Sano Nggoang, Manggarai Barat Tahun Pelajaran 2016/2017. Jurnal Jime, Vol. 3, Nomor 1 April 2017, 303-304.

Wawancara Guru TNCC Banda Aceh pada 16 September 2020

Wiedarti, Pangesti. dkk. Desain Induk Gerakan Literasi Sekolah. Jakarta: Direktorat
Jenderal Pendidikan Dasar dan Menengah Kementerian Pendidika dan Kebudayaan. 2016.

Yanti, Lena. Pengembangan Kompetensi Profesional Guru Program Khusus (Konsep dan Teori). Banda Aceh: Bandar Publishing. 2017.

Yuliana, Cut Putro, dkk. Manajemen Kinerja Guru Pustakwan dalam Pemberdayaan Perpustakaan Sekolah Pada SMAN 2 Meulaboh, Jurnal LIBRIA Vol. 11 Nomor 1 Juni 2019, 52-53.

Zamzani, Sumaryadi. Penggunaan Bahasa Indonesia Dalam Tesis Mahasiswa IKIP Yogyakarta. Yogyakarta: Cakrawala Pendidikan. 1985. 